\title{
FEITOSA, LOURDES CONDE. \\ THE ARCHEOLOGY OF GENDER, LOVE AND \\ SEXUALITY IN POMPEII. OXFORD: ARCHEOPRESS,
}

\section{63P.}

André Pereira Rocha ${ }^{1}$

In her research, the result of her doctoral thesis and translated by Miriam Adelman, Lourdes Feitosa analyses the conceptions of "man" and "woman", starting from the graffiti of the city of Pompeii and focusing on the manifestations of the non-elite classes. To achieve that, themes such as "gender", "love" and "sexuality" became the center of her concerns. These expressions, which appear on the pompeian walls, reveal a perception of the history usually ignored by the traditional historiography.

Feitosa comes from a perspective that became important to the historiography since the 1970's, but which gained real expression in the 2000's. Gender issues in history reflects the contemporaneity necessities; before a minor problem for the Antiquity and the Ancient Rome, it now become a important question to the studies about the relations of power and the popular culture. The influence of Paul Veyne and Michel Foucault can be viewed in her research about sexuality.

Thus, the analysis of the concepts of "masculine" and "feminine" has the objective to scape from stereotyped perceptions. One of her criticisms over the traditional historiography aims, precisely, the rigid concepts of gender and sexuality, deeply influenced by the historians of the nineteenth century. The historical context reflection over their historiographical writing is also pulled into question. The author, as such, produces a specific perception of the historian's craft and their relations with the past along her text.

${ }^{1}$ Programa de Pós-graduação em História - Mestrado. Universidade Federal de São Paulo - Guarulhos, SP, Brasil. e-mail: andrerochabae@yahoo.com.br 
The graffiti, focus of this research, could reveal not only the individual manifestation from a person, but, as Feitosa aims, the political position constructed collectively. Much more than a linguistic expression, she concerns herself with the locations which these inscriptions appear. Her whole work was based on the tome IV of the Corpus Inscriptionum Latinarum (CIL). According her research and what is expose in the archaeological researches, the inscriptions about amourose expressions, in a broad sense, are in every city, occupying the same public places of hundred of other writings. Such places reveal the daily life and the commonplace this theme.

The work is divided in five chapters. The Chapter 1 is entitled "Gender, love and sexuality: methodological perspectives", the Chapter 2 "Representations of love and sexuality in academic literature", the Chapter 3 "Pompeii: constructing a historical scenario", the Chapter 4 "Graffiti as a form of popular expression" and the Chapter 5, and last, "Love and sexuality on wall inscriptions".

The first one is centered over the construction of the theoretical and methodological tools used in the research. Inserted in a specific historiography, she developed it following the concerns and questions of the history of love and sexuality which appears in the final decades of the twentieth century. A profusion of authors are brought to fore, such as Michel Foucault, Roger Chartier, Roland Barthes, Hayden White and David Harlan, for example. However, two affirmatives characterize the Feitosa's work: the historical knowledge as discourse, a subjective, politic and historical perspective (Feitosa, 2013: 2), and the use of the micro-history, because it reveals the social tensions with the analyses of a particular person, group or event (Feitosa, 2013: 2). Feitosa create here the bases of the analyses over the Pompeii and the inscriptions on the walls, and it reveals itself more clearly in the following chapters.

At same time, there is the construction of the concept of "gender", based in authors such as George Duby, Michelle Perrot and Michele D'Avino. In spite of the approach of gender history and the women's history, Feitosa has a care that differs and the limits them both. Much more than anticipate a schematic concept of "masculine" and "feminine", she analyse the plurality of this conceptions among romans in the Antiquity. Also, it's possible to see her approach of the thinking of Quentin Skinner and her worries about the specificity on the studies over the certains terms.

In Chapter 2, there is a construction of the traditional historiography and the studies about love and sexuality in Ancient Rome. While criticizing the bias of the researches of the eighteenth and nineteenth centuries, and exposing the different paths taken by contemporaneous historiography, she aims, as important objective of the research, to grasp the meanings of the amorous behavior of the popular classes. It was only in the last decades of the twentieth century that importants studies about this theme arose, aiming to reach a historical construction of the sexuality, seeing the sexual behavior as 
a specific perception within a given context. Feitosa recuperates authors such as Antonio Vanore and Eva Canterella in a similar way as she has done with Foucault and Veyne.

In the third Chapter, Feitosa exposes the explicit use of the micro-history. She puts the city of Pompeii inside the world of the roman dynamics, in the same hand, she shows the specific spaces of public manifestation, present on the walls of the city, spaces that remain until these days. The objective of expose the key factors about the economic and the politic history of the Rome reveals her perception of the Ancient Roman world, when designing the possibility of analysing the epigraphy inside of the multifaceted context of the roman culture.

For this intent, working in a fluid world, the conception of "popular culture" is discuss and defined in the Chapter 4 . The most important in this analysis is the point of view based over the jurisdictional position of the romans, known as ingenuus, libertus and seruus. From this perspective, the ingenuus created a frame of the world over the libertus and serouus. At the same time, the dominance is based in a masculine conception of active of the white man from the roman elite. In this way, she constructs the popular culture of the Ancient Rome through the concepts of gender, fulfilling the need of the multifaceted manifestation from this context.

In the end, in the fifth Chapter, the author select two terms to explore the love and sexuality on the walls of Pompeii: futuere and cunnum lingere. Starting from this two sexual practices, Feitosa elaborate a clear exposition about the construction of the masculinity and the femininity and how these practices are intimately reflected in more features than merely the sexual ones. Thereby, the relations of power, the social position of men and women and the juridical situation of both stablish a specific historical horizon when analysed along the linguistic representations on the walls, of which the conceptual creation of the masculinity figure, guided by the ideia of virility, reverberates over the entire roman society.

Anyway, the historical discourse produced by Feitosa increases the possibilities of analyse of the Ancient Roman world. The minuteness of a research based on the linguistic manifestation of love and sexuality expands to a complex perception of the multifaceted relations existent in the different levels of the society. In this way, to focus in the studies of the gender and sexuality, as said by the author, "gives way to a view of the masculine constructed in relation to the feminine" (Feitosa, 2013: 54), revealing particular features of these meanings in the Antiquity while, at the same time, criticizes a traditional historiography that did not privileged the women in History. 